\title{
COMPARISON OF THE CONSTANT INFUSION AND URINE COLLECTION TECHNIQUES FOR THE MEASUREMENT OF RENAL FUNCTION ${ }^{1}$
}

\author{
By EUGENE Y. BERGER, SAUL J. FARBER, AND DAVID P. EARLE, JR. \\ WITH THE TECHNICAL ASSISTANCE OF ROSALYN JACKENTHAL \\ (From the Third [New York University] Research Service, Goldwater Memorial Hospital, \\ and the Department of Medicine, New York University College of Medicine, \\ New York City)
}

(Received for publication May 8, 1948)

For any exogenous substance which is neither metabolized, stored nor excreted otherwise than in the urine, the rate of excretion must be equal to the rate of infusion under conditions where its plasma level and volume of distribution are constant. This steady state, as indicated by a constant plasma level, will be designated infusion equilibrium.

A simplified method for the measurement of glomerular filtration rate and the effective renal plasma flow based upon the above principle has been described elsewhere (1). In the application of the principle, the rate of infusion, $I V$ (where $I$ is the concentration in $\mathrm{mg}$. per $\mathrm{ml}$. of infusion fluid and $V$ is the volume of fluid injected in $\mathrm{ml}$. per minute), can be substituted for the rate of excretion, $U V$, in the clearance calculation, i.e., $I V / P=$ $U V / P$. The procedure, therefore, obviates the necessity of bladder catheterization and the errors inherent in urine collection.

The, study presented here embodies further observations, obtained under normal and abnormal circumstances, on the correlation of inulin and p-aminohippuric acid clearances as measured by urine collections with those measured simultaneously by the infusion technique, and on the application of the infusion technique to the measurement of p-aminohippuric acid Tm.

\section{EXPERIMENTAL PROCEDURE}

Glomerular filtration rate and renal plasma flow were estimated from the clearances $(2,3)$ of inulin and $p$ aminohippurate $(\mathrm{PAH})^{2}$ by the usual urine collection technique involving the use of a multi-eyed catheter and

1 This investigation was supported by a grant from the Life Insurance Medical Research Fund.

2 The authors are indebted to the Medical Research Division of Sharp and Dohme, Inc., of Glenolden, Pa., for generous supplies of sodium-p-aminohippurate in ampules. bladder rinses with water and air. The maximum rate of excretion of PAH by the tubules ( $\left.T \mathrm{~m}_{\mathrm{PAB}}\right)$ was also measured in some of the experiments (3). Three or more serial urine collection periods of 15 to 30 minutes each were measured.

Priming injections of inulin and $\mathrm{PAH}$ were given intravenously in amounts calculated to achieve plasma levels of 5 to 20 and 2 to $3 \mathrm{mg}$. per cent respectively. The approximate volume of distribution for an average normal subject was taken as 15 liters for inulin and 20 liters for PAH. Priming injections of 2 grams of inulin and 0.8 gram sodium p-aminohippurate were frequently used and generally resulted in plasma levels of 10 to 15 and 2.5 to $3.0 \mathrm{mg}$. per cent respectively. Priming doses were modified for persons of unusual size, and were greatly increased in the presence of edema.

The sustaining infusions were delivered by a pump at a rate calculated, on the basis of estimated renal function, to maintain the desired plasma concentrations. For example, if the estimated filtration rate was $100 \mathrm{ml}$. per minute and if the plasma inulin concentration desired, and presumably achieved by the priming injection, was 5 mg. per cent then each minute $100 \times 0.05$ or $5 \mathrm{mg}$. would be excreted in the urine. The sustaining infusion, therefore, would deliver $5 \mathrm{mg}$. of inulin per minute.

For $T m_{\mathrm{PAB}}$ measurements the desired plasma PAH level was roughly calculated for a load/Tm ratio of 2 from the equation:

Plasma PAH level $\times$ renal plasma flow (measured or estimated)

$$
\text { Anticipated } T m_{\mathrm{PAB}}
$$

The priming PAH dose was calculated from the desired plasma PAH level and a volume of distribution of 20 liters for the individual of average size.

The estimated plasma PAH level was substituted in the formula (3): Anticipated $T m_{\mathrm{PAH}}=U V-0.83 C_{\mathrm{IN}} P_{\mathrm{PAB}}$, where $C_{\mathrm{IN}}$ represents the anticipated inulin clearance. The equation was solved for the term $U V$ which represents the amount of PAH excreted in the urine per unit of time and, therefore, the amount which must also be delivered by the sustaining infusion.

The infusion pump used in the early experiments consisted of a worm-drive rod powered by a constant speed motor that pushed on the plunger of a $50-$ or $100-\mathrm{ml}$. syringe. The rate of delivery with the $50-\mathrm{ml}$. syringe 
was approximately $0.12 \mathrm{ml}$. per minute, and approximately $0.25 \mathrm{ml}$. per minute with a $100-\mathrm{ml}$. syringe. This pump was inconvenient for use in experiments lasting more than three hours since the syringe had to be refilled and the rate of delivery of fluid could be varied only by changing to a larger or smaller syringe.

Subsequently a Bayliss infusion pump was adopted consisting of a series of rollers which rotated in ferris wheel fashion compressing a short length of the infusion tubing. The pump was powered by a constant speed electric motor. The rate of revolution of the wheel was regulated by a variable speed transmission. Some surging occurred with this pump, but over periods greater than one minute the rate of delivery was constant. Delivery rates with this pump using ordinary intravenous rubber tubing could be varied at will between 1 and 3 ml. per minute.

Generally, infusion equilibrium, as indicated by constant plasma inulin and $\mathrm{PAH}$ concentrations, was achieved at the end of one hour in normal subjects. The period allowed for attainment of equilibrium was frequently extended to one and one-half hours, and even then there were a few instances where the plasma levels were still changing during subsequent experimental periods. Throughout this work all infusion technique clearances are based on plasma inulin and PAH levels obtained at the approximate mid-points of the standard urine collection periods.

\section{CHEMICAL METHODS}

Inulin was determined by Harrison's modification (4) of the colorimetric method of Alving, Rubin and Miller (5). Protein-free filtrates were obtained by the Somogyi zinc precipitation (6). For inulin analysis, infusion fluids, urines and plasmas were all treated with yeast so that all analyses would be comparable. Plasma, obtained before the injection of inulin, was used as a blank.

PAH was measured by the Bratton-Marshall reaction (7). Since $\mathrm{PAH}$ is conjugated by man it is necessary in the infusion technique to determine "total" PAH after hydrolysis. Proteins were precipitated with $3 \mathrm{ml}$. of 15 per cent trichloracetic acid per $1 \mathrm{ml}$. of plasma and 10 $\mathrm{ml}$. of water. Conjugated $\mathrm{PAH}$ was hydrolyzed by heating $10 \mathrm{ml}$. of the filtrate with $1 \mathrm{ml}$. of $1.1 \mathrm{~N}$ hydrochloric acid for one hour in a boiling water bath. One $\mathrm{ml}$. $\mathrm{N}$ hydrochloric acid was added to $5 \mathrm{ml}$. of the hydrolyzed filtrate in a colorimeter tube before addition of the Bratton-Marshall reagents. Plasma blanks were routinely done for each experiment.

A small amount of PAH was destroyed when subjected to the above hydrolysis procedure, the amount increasing with time. On the other hand, hydrolysis of acetyl-PAH increased with duration of heating. The conditions outlined above were chosen as those which permit the greatest degree of hydrolysis with the least destruction of PAH. When known amounts of acetyl$\mathrm{PAH}$ were subjected to the procedure described above, the average recovery was 96 per cent of theory. Since the conjugated compound was apparently not subjected to destruction during the procedure, it was impossible to hydrolyze the infusion fluids and the plasma filtrates and urines so that they were precisely comparable.

At the high plasma PAH levels maintained during the $T m_{\text {PAB }}$ measurements, the fraction of the compound conjugated was so small, and could not be detected, and hydrolysis was, therefore, unnecessary (3).

\section{RESULTS}

Glomerular filtration rate and renal plasma flow as measured by the infusion pump technique were compared with simultaneous measurements by the usual methods involving serial urine collections. Unless stated otherwise, all clearance data recorded in the table and figures represent the average of three or more consecutive periods. The clearance values are not corrected for surface area.

For present purposes it was assumed that infusion equilibrium existed whenever there was less than a 6 per cent variation between the serial plasma inulin and $\mathrm{PAH}$ concentrations. The variations in plasma level were within the limits of error of the methods of analysis in the majority of experiments.

The average urine/infusion clearance ratio for inulin was $1.00(\sigma=0.054)$ in 45 experiments in 26 subjects with normal kidneys and ten with renal disease. These data are summarized in Figure $1 .^{3}$ The glomerular filtration rates in these subjects ranged from 168 to $14 \mathrm{ml}$. per minute. In general, there was less variation among the individual clearances in any given experiment as measured by the infusion method than among the clearances as measured by urine collections. For example, comparisons between the two techniques were made during ten consecutive periods in a single experiment. The range in filtration rates measured by urine collection was 122 to $139 \mathrm{ml}$. per minute, but only 124 to 130 by the infusion technique.

The average urine/infusion clearance ratio for $\mathrm{PAH}$ in 26 experiments in 23 of the same subjects was $0.975(0=0.049)$. These data are shown in Figure $2 .^{3}$ It is likely that the slightly low urine/infusion ratio is the result of some loss

\footnotetext{
${ }^{3}$ For the sake of clear presentation, one datum that fell below $25 \mathrm{ml}$. per minute was omitted from Figure 1, three data that fell below $300 \mathrm{ml}$. per minute were omitted from Figure 2, and two data that fell below 30 mg. per minute were omitted from Figure 3.
} 
COMPARISON OF INULIM. CLEARANGE AS MEASURED OY URINE AND INFUSION

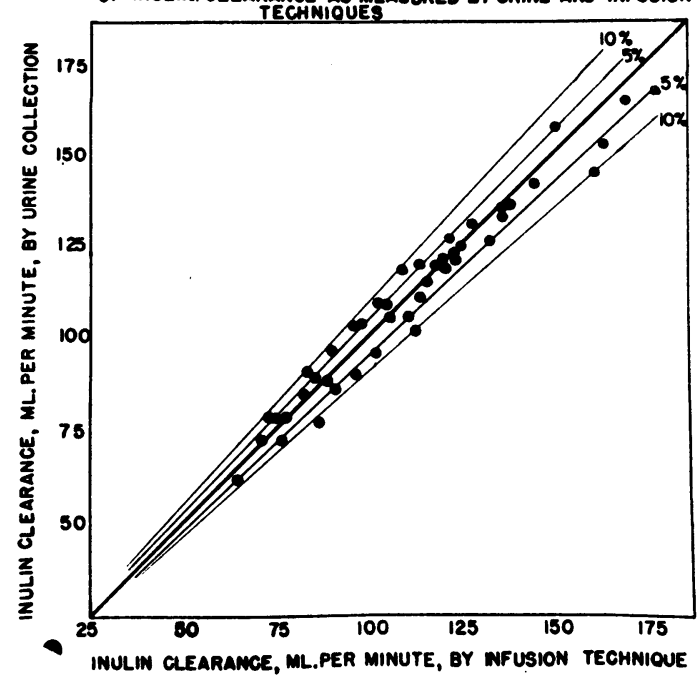

FIG. 1

of $\mathrm{PAH}$ during hydrolysis of the urines (see Methods). The filtration fraction (ratio of glomerular filtration to plasma flow) as given by the urine and infusion techniques was calculated for the 26 experiments where both functions were measured simultaneously and the average of the ratio of the two filtration fractions so obtained was 1.045 $(\sigma=0.055)$. The average urine/infusion clearance ratio for inulin in these 26 experiments was 1.02 , which in part accounts for the high ratio for the filtration fractions as calculated independently. The relatively low urine $\mathrm{PAH}$ clearance due to loss on hydrolysis (see above) is another factor.

During the period throughout which the experiments recorded in the figures were performed, there were also a number of unsuccessful comparisons between the urine collection and infusion techniques. Four instances where there were obvious difficulties with the method of analysis of inulin and $\mathrm{PAH}$ are legitimately dismissed from further consideration. There were four other instances where there was either leakage of infusion fluid or infiltration of the fluid into the subcutaneous tissues around the venepuncture. Accidents of this nature invalidate the infusion technique and are attended by rapidly falling plasma inulin and $\mathrm{PAH}$ levels.

Urine collections were so inaccurate in four experiments that no comparison of the urine collection and infusion clearances could be made. However, in these four instances, the ratios of the filtra- tion fractions, as calculated by the two techniques, which are unaffected by inaccuracies of urine collection, were $1.00,0.95,0.95$ and 0.92 .

There were six instances where the plasma inulin levels were not constant enough to assume infusion equilibrium and four instances where the $\mathrm{PAH}$ levels were at fault. In all these instances there was a progressive decline in the plasma levels. The infusion clearance usually approached the urine clearance as the experiment progressed, indicating that equilibrium, and thus a valid infusion technique clearance, would have been achieved had the experiments lasted longer.

Attempts to measure filtration rate and plasma flow by the infusion technique were made in five patients with considerable edema. In four instances it was obvious that equilibrium had not been achieved, with progressively falling plasma levels in three instances and very erratic levels in a fourth patient with marked anasarca. In the fifth subject, who had rheumatic heart disease and a pleural effusion but only slight pitting edema of the ankles, the plasma inulin and $\mathrm{PAH}$ levels were quite constant for five consecutive 20-minute periods, starting one and one-half hours after the priming infusion. The filtration rate and renal plasma flow were 69.0 and $144 \mathrm{ml}$. per minute by urine collections and 76 and $144 \mathrm{ml}$. per minute by the infusion pump technique. However, that there

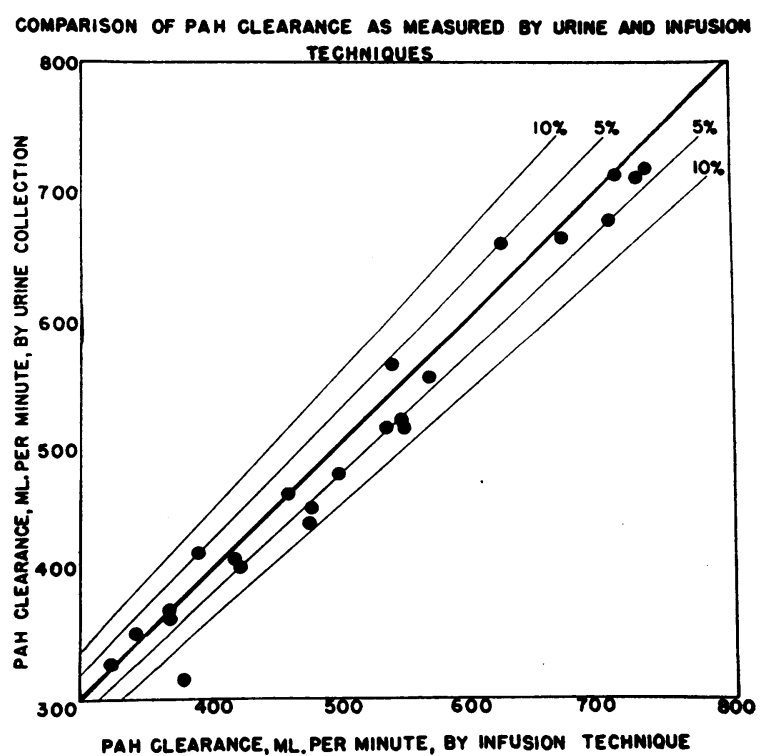

FIG. 2 
was not a true equilibrium, in spite of constant plasma drug levels, was indicated by the observation that the concentrations of inulin and PAH in the pleural fluid were respectively 20 and 40 per cent of the concentrations in plasma.

Renal functions as measured by urine collections were much lower than anticipated in three patients with renal disease. The true filtration rates in these patients ranged from 17 to $33 \mathrm{ml}$. per minute. Amounts of inulin and $\mathrm{PAH}$ infused in these experiments exceeded by 40 to 100 per cent the amounts excreted. The calculated infusion technique clearances were, therefore, erroneous, although the plasma levels, obtained at 15to 20-minute intervals, were quite stable and falsely suggested the presence of equilibrium. ${ }^{4}$ A similar situation in regard to $\mathrm{PAH}$ clearances and $T \boldsymbol{m}_{\mathbf{P A H}}$ was observed in the same patients.

The filtration rate is sometimes changed by the intravenous administration of infusions containing large amounts of PAH $(8,9)$ or mannitol $(10)$. The effect of infusions containing one of these substances, or glucose, on the correspondence between urine collection and infusion technique inulin clearances was studied in 14 experiments. In each experiment the filtration rate was measured during three control periods prior to the administration of the test infusion. At least 30 minutes were per-

\footnotetext{
4 The lower a renal function, the more likely is the possibility of wrongly estimating that function and, therefore, of grossly miscalculating the amount of material to be infused. Generally, the true function is overestimated and too much material is administered in the sustaining infusion, upon which the infusion technique clearance is calculated. In the presence of reduced renal function, even if this function has been overestimated for purposes of calculating the sustaining infusion doses, these doses are relatively small and any amounts administered (in excess of the amounts excreted) are distributed over a large volume of fluid. Change in plasma drug level, therefore, will not be rapid. In addition, the lower the renal function, the greater importance does the initial priming dose assume in determining the plasma level, since relatively small amounts of material are added by the sustaining infusion and little is lost through the kidneys. However, the material infused in excess to that excreted during the three experiments in question should have raised the plasma drug levels by measurable amounts. The observed absence of change in plasma level can only be explained by assuming that material was diffusing into further and further recesses of the extracellular fluid. Why this occurred in these patients with reduced renal function is not known.
}

mitted to elapse after the beginning of a test infusion before three post-infusion clearances were measured. There were eight instances in which there was a greater than 5 per cent decrease in filtration rate as measured by urine collection, the average decrease being 12 per cent. The average decrease in filtration rate by the infusion technique was 4.1 per cent in the same subjects. In two of these eight subjects there was a slight increase rather than decrease in filtration rate as measured by the infusion technique. In the remaining six subjects there were no significant changes in filtration rates as measured by either technique.

Similar studies were made on the effects of adrenalin, cinchona alkaloids and intravenous triple typhoid vaccine on glomerular filtration rate, renal plasma flow and the filtration fraction. These data are shown in Table I. Adrenalin typically and acutely decreases the plasma flow and increases the filtration fraction (11) while typhoid vaccine results in a gradual but marked increase in plasma flow and a decrease in filtration fraction (11). The effect of the cinchona alkaloids on these functions in man is variable (12), but generally there is a decrease in the plasma flow and an increase in the filtration fraction, especially after quinine. Since the renal functions varied continuously throughout all these experiments, the periods showing the maximum change are recorded in Table $I$ in addition to the averages.

There were seven experiments in which there was an average maximal increase of 35 per cent in the $U V$ filtration fraction. The average maximal increase in the $I V$ filtration fraction in the same experiments was 20 per cent. The average maximal decrease in the $U V$ filtration fraction in five typhoid vaccine experiments and one cinchona alkaloid study was 35 per cent in contrast to an average maximal 27 per cent decrease in $I V$ filtration fraction. In all these experiments the $I V$ changes in plasma flow were in the same direction as the $U V$ changes, and in most the maximal change in the infusion clearances occurred during the same or next period subsequent to the maximum $U V$ clearance changes.

Measurements of the maximal rate of excretion of $\mathrm{PAH}$ by the renal tubules $\left(T \mathrm{~m}_{\mathrm{PAH}}\right)$ by the $I V$ technique were compared to the usual $U V$ measurements in 17 experiments. Urine collections 
TABLE I

Comparison of renal functions by urine and pump techniques during acute changes

\begin{tabular}{|c|c|c|c|c|c|c|c|c|c|c|}
\hline \multirow[b]{2}{*}{ Patient } & \multirow[b]{2}{*}{ Procedure } & \multirow{2}{*}{$\begin{array}{c}\text { Number } \\
\text { of } \\
\text { Periods }\end{array}$} & \multicolumn{2}{|c|}{$\begin{array}{l}\text { Inulin } \\
\text { Clearance }\end{array}$} & \multicolumn{2}{|c|}{$\begin{array}{c}\text { PAH } \\
\text { Clearance }\end{array}$} & \multicolumn{2}{|c|}{ Filtrate fraction } & \multicolumn{2}{|c|}{ Change in filtrate fraction } \\
\hline & & & $\begin{array}{c}\text { Calculated } \\
\text { on basis of } \\
\text { urine } \\
\text { collections }\end{array}$ & $\begin{array}{c}\text { Calculated } \\
\text { on basis of } \\
\text { infusion } \\
\text { technique }\end{array}$ & $\begin{array}{c}\text { Calculated } \\
\text { on basis of } \\
\text { urine } \\
\text { collections }\end{array}$ & $\begin{array}{c}\text { Calculated } \\
\text { on basis of } \\
\text { infusion } \\
\text { technique }\end{array}$ & $\begin{array}{c}\text { Calculated } \\
\text { on basis of } \\
\text { urine } \\
\text { collections }\end{array}$ & $\begin{array}{c}\text { Calculated } \\
\text { on basis of } \\
\text { infusion } \\
\text { technique }\end{array}$ & $\begin{array}{l}\text { Calculated } \\
\text { on basis of } \\
\text { urine } \\
\text { collections }\end{array}$ & $\begin{array}{c}\text { Calculated } \\
\text { on basis of } \\
\text { infusion } \\
\text { technique }\end{array}$ \\
\hline Las & $\begin{array}{l}\text { Control } \\
\text { Adrenalin } \\
\text { Max. adrenalin }\end{array}$ & $\begin{array}{l}3 \\
3 \\
1\end{array}$ & $\begin{array}{l}119 \\
134 \\
136\end{array}$ & $\begin{array}{l}114 \\
125 \\
131\end{array}$ & $\begin{array}{l}670 \\
614 \\
546\end{array}$ & $\begin{array}{l}701 \\
653 \\
624\end{array}$ & $\begin{array}{l}\text { per cent } \\
17.8 \\
21.9 \\
22.3\end{array}$ & $\begin{array}{l}\text { per cent } \\
16.2 \\
19.2 \\
19.4\end{array}$ & $\begin{array}{l}\text { per cent } \\
+23.0 \\
+25.3\end{array}$ & $\begin{array}{l}\text { per cent } \\
+18.6 \\
+19.8\end{array}$ \\
\hline Har & $\begin{array}{l}\text { Control } \\
\text { Adrenalin } \\
\text { Max. adrenalin }\end{array}$ & $\begin{array}{l}3 \\
3 \\
1\end{array}$ & $\begin{array}{l}95.6 \\
109 \\
115\end{array}$ & $\begin{array}{r}86.2 \\
94.6 \\
102\end{array}$ & $\begin{array}{l}400 \\
412 \\
390\end{array}$ & $\begin{array}{l}415 \\
422 \\
393\end{array}$ & $\begin{array}{l}23.8 \\
26.4 \\
27.3\end{array}$ & $\begin{array}{l}20.8 \\
22.3 \\
23.3\end{array}$ & $\begin{array}{r}+10.9 \\
+14.7\end{array}$ & $\begin{array}{r}+7.2 \\
+12.0\end{array}$ \\
\hline Aik & $\begin{array}{l}\text { Control } \\
\text { Adrenalin } \\
\text { Max. adrenalin }\end{array}$ & $\begin{array}{l}3 \\
3 \\
1\end{array}$ & $\begin{array}{l}70.9 \\
63.8\end{array}$ & $\begin{array}{l}69.4 \\
67.8\end{array}$ & $\begin{array}{l}412 \\
289 \\
263\end{array}$ & $\begin{array}{l}388 \\
324 \\
298\end{array}$ & $\begin{array}{l}17.2 \\
22.1 \\
25.0\end{array}$ & $\begin{array}{l}16.7 \\
20.9 \\
22.1\end{array}$ & $\begin{array}{l}+28.5 \\
+45.5\end{array}$ & $\begin{array}{l}+25.2 \\
+32.4\end{array}$ \\
\hline Hen & $\begin{array}{l}\text { Control } \\
\text { Quinine } \\
\text { Max. quinine }\end{array}$ & $\begin{array}{l}3 \\
6 \\
1\end{array}$ & $\begin{array}{l}152 \\
146 \\
136\end{array}$ & $\begin{array}{l}164 \\
156 \\
147\end{array}$ & $\begin{array}{l}654 \\
502 \\
368\end{array}$ & $\begin{array}{l}661 \\
584 \\
518\end{array}$ & $\begin{array}{l}23.2 \\
29.0 \\
36.9\end{array}$ & $\begin{array}{l}24.7 \\
26.7 \\
29.3\end{array}$ & $\begin{array}{l}+25.0 \\
+59.0\end{array}$ & $\begin{array}{r}+8.1 \\
+18.6\end{array}$ \\
\hline Mil & $\begin{array}{l}\text { Control } \\
\text { Quinine } \\
\text { Max. quinine }\end{array}$ & $\begin{array}{l}3 \\
6 \\
1\end{array}$ & $\begin{array}{l}115 \\
110 \\
111\end{array}$ & $\begin{array}{l}116 \\
113 \\
111\end{array}$ & $\begin{array}{l}624 \\
417 \\
378\end{array}$ & $\begin{array}{l}608 \\
499 \\
455\end{array}$ & $\begin{array}{l}18.4 \\
26.4 \\
29.4\end{array}$ & $\begin{array}{l}19.1 \\
22.6 \\
24.4\end{array}$ & $\begin{array}{l}+43.5 \\
+59.0\end{array}$ & $\begin{array}{l}+18.4 \\
+27.8\end{array}$ \\
\hline Joh & $\begin{array}{l}\text { Control } \\
\text { Quinine } \\
\text { Max. quinine }\end{array}$ & $\begin{array}{l}3 \\
5 \\
1\end{array}$ & $\begin{array}{c}103 \\
95.1 \\
86.2\end{array}$ & $\begin{array}{l}95.4 \\
88.5 \\
84.2\end{array}$ & $\begin{array}{l}509 \\
419 \\
374\end{array}$ & $\begin{array}{l}528 \\
455 \\
499\end{array}$ & $\begin{array}{l}20.3 \\
22.7 \\
25.2\end{array}$ & $\begin{array}{l}18.1 \\
19.5 \\
20.6\end{array}$ & $\begin{array}{r}+11.8 \\
+24.1\end{array}$ & $\begin{array}{r}+7.7 \\
+13.8\end{array}$ \\
\hline \multirow[t]{2}{*}{ Gri } & \multirow[t]{2}{*}{$\begin{array}{l}\text { Control } \\
\text { Cinchonine } \\
\text { Max. cinchonine }\end{array}$} & \multirow[t]{2}{*}{$\begin{array}{l}2 \\
6 \\
1\end{array}$} & \multirow[t]{2}{*}{$\begin{array}{l}88.6 \\
86.0 \\
88.9\end{array}$} & \multirow[t]{2}{*}{$\begin{array}{l}86.5 \\
86.1 \\
87.6\end{array}$} & \multirow[t]{2}{*}{$\begin{array}{l}447 \\
422 \\
380\end{array}$} & \multirow[t]{2}{*}{$\begin{array}{l}475 \\
439 \\
415\end{array}$} & \multirow[t]{2}{*}{$\begin{array}{l}19.8 \\
20.4 \\
23.4\end{array}$} & $\begin{array}{l}18.2 \\
19.7 \\
21.1\end{array}$ & $\begin{array}{l}+3.0 \\
+18.2\end{array}$ & $\begin{array}{r}+8.2 \\
+15.9\end{array}$ \\
\hline & & & & & & & & $\begin{array}{l}\text { Average } \\
\text { Maximum }\end{array}$ & $\begin{array}{l}+20.7 \\
+35.1\end{array}$ & $\begin{array}{l}+13.3 \\
+20.0\end{array}$ \\
\hline Mil & $\begin{array}{l}\text { Control } \\
\text { Quinidine } \\
\text { Max. quinoline }\end{array}$ & $\begin{array}{l}3 \\
6 \\
1\end{array}$ & $\begin{array}{l}123 \\
125 \\
116\end{array}$ & $\begin{array}{l}121 \\
128 \\
123\end{array}$ & $\begin{array}{l}512 \\
616 \\
710\end{array}$ & $\begin{array}{l}541 \\
561 \\
678\end{array}$ & $\begin{array}{l}24.0 \\
20.3 \\
16.4\end{array}$ & $\begin{array}{l}22.3 \\
22.8 \\
18.2\end{array}$ & $\begin{array}{l}-15.4 \\
-31.6\end{array}$ & $\begin{array}{r}2.2 \\
-18.4\end{array}$ \\
\hline Sol & $\begin{array}{l}\text { 1st typhoid } \\
\text { Typhoid } \\
\text { Max. Typhoid }\end{array}$ & $\begin{array}{l}6 \\
1\end{array}$ & $\begin{array}{l}146 \\
135 \\
136\end{array}$ & $\begin{array}{l}131 \\
136 \\
141\end{array}$ & $\begin{array}{l}671 \\
830 \\
999\end{array}$ & $\begin{array}{l}612 \\
820 \\
978\end{array}$ & $\begin{array}{l}21.8 \\
16.3 \\
13.6\end{array}$ & $\begin{array}{l}21.4 \\
16.6 \\
14.4\end{array}$ & $\begin{array}{l}-25.5 \\
-37.6\end{array}$ & $\begin{array}{l}-22.5 \\
-32.8\end{array}$ \\
\hline Per & $\begin{array}{l}\text { 1st typhoid } \\
\text { Typhoid } \\
\text { Max. typhoid }\end{array}$ & $\begin{array}{l}1 \\
5 \\
1\end{array}$ & $\begin{array}{l}79.9 \\
77.5 \\
71.9\end{array}$ & $\begin{array}{l}72.7 \\
73.4 \\
72.4\end{array}$ & $\begin{array}{l}361 \\
510 \\
557\end{array}$ & $\begin{array}{l}304 \\
426 \\
503\end{array}$ & $\begin{array}{l}20.5 \\
15.2 \\
12.9\end{array}$ & $\begin{array}{l}23.9 \\
17.2 \\
14.4\end{array}$ & $\begin{array}{l}-25.9 \\
-37.0\end{array}$ & $\begin{array}{l}-28.1 \\
-39.9\end{array}$ \\
\hline Rio & $\begin{array}{l}\text { 1st typhoid } \\
\text { Typhoid } \\
\text { Max. typhoid }\end{array}$ & $\begin{array}{l}1 \\
5 \\
1\end{array}$ & $\begin{array}{l}74.9 \\
71.4 \\
66.2\end{array}$ & $\begin{array}{l}79.2 \\
76.1 \\
74.3\end{array}$ & $\begin{array}{l}483 \\
542 \\
593\end{array}$ & $\begin{array}{l}453 \\
532 \\
570\end{array}$ & $\begin{array}{l}14.7 \\
13.2 \\
11.2\end{array}$ & $\begin{array}{l}15.3 \\
14.3 \\
13.5\end{array}$ & $\begin{array}{l}-10.2 \\
-23.9\end{array}$ & $\begin{array}{l}-6.5 \\
-11.8\end{array}$ \\
\hline \multirow[t]{2}{*}{ Aik } & \multirow[t]{2}{*}{$\begin{array}{l}\text { 1st typhoid } \\
\text { Typhoid } \\
\text { Max. typhoid }\end{array}$} & \multirow[t]{2}{*}{$\begin{array}{l}1 \\
6 \\
1\end{array}$} & \multirow[t]{2}{*}{$\begin{array}{l}68.6 \\
60.6 \\
53.6\end{array}$} & \multirow[t]{2}{*}{$\begin{array}{l}66.8 \\
64.8 \\
64.1\end{array}$} & \multirow[t]{2}{*}{$\begin{array}{l}354 \\
414 \\
506\end{array}$} & \multirow[t]{2}{*}{$\begin{array}{l}348 \\
395 \\
479\end{array}$} & \multirow[t]{2}{*}{$\begin{array}{l}19.4 \\
14.6 \\
10.6\end{array}$} & $\begin{array}{l}19.2 \\
16.4 \\
13.4\end{array}$ & $\begin{array}{l}-4.8 \\
-45.5\end{array}$ & $\begin{array}{l}-14.6 \\
-30.2\end{array}$ \\
\hline & & & & & & & & $\begin{array}{l}\text { Average } \\
\text { Maximum }\end{array}$ & $\begin{array}{l}-16.4 \\
-35.1\end{array}$ & $\begin{array}{l}-14.8 \\
-26.6\end{array}$ \\
\hline
\end{tabular}

were obviously faulty in one experiment, while in two the load of $\mathrm{PAH}$ was below that necessary to saturate the excretory mechanism. In another four experiments the load of PAH was apparently too large (load/ $T m_{\mathbf{P A H}}$ ratios greater than 4.0 ) to permit the attainment of equilibrium. Eight of the remaining ten experiments (load/ $T m_{\mathbf{P A H}}$ ratios all between 1.5 and 4.0 ) are summarized in Figure $3 .^{3}$ The calculations for the $T m_{\text {PAH }}$ values shown in Figure 3 involve the respective $U V$ and 


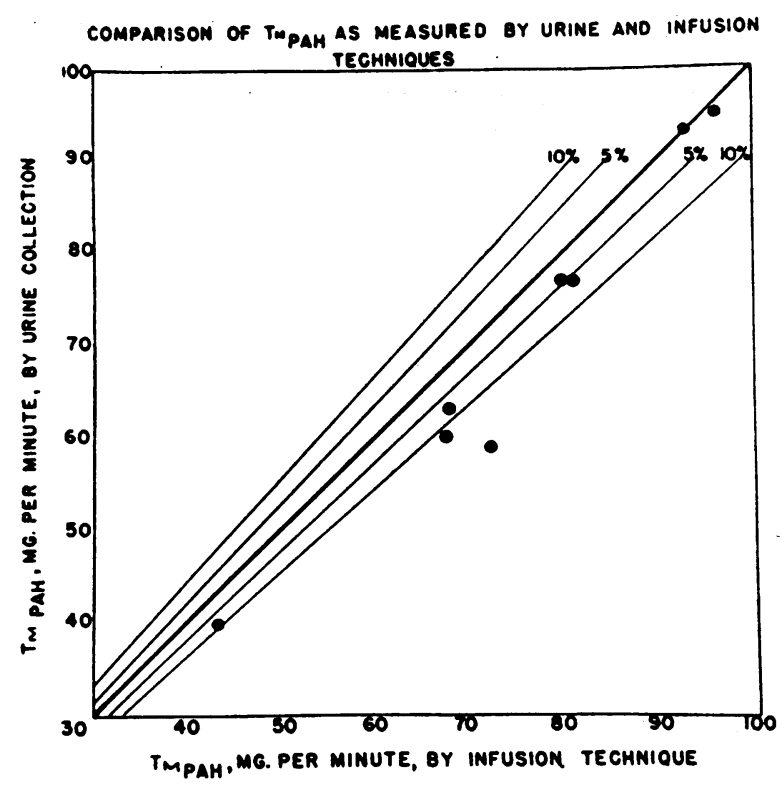

FIG. 3

IV filtration rates, which in themselves are subject to some differences, especially during the infusion of the relatively large amounts of PAH necessary for the $T m_{\text {PAH }}$ measurements (see above). The actual mgs. per minute of $\mathrm{PAH}$ infused and excreted afford a direct comparison between the $U V$ and $I V$ techniques. The average ratio between $\mathrm{PAH}$ infused and excreted was 0.95 in the ten experiments with a range of 0.84 to 1.00 while the average ratio of $U V$ to $I V T m_{\mathrm{PAH}}$ was 0.93 .

\section{COMMENTS}

Clearances of inulin and $\mathrm{PAH}$ when calculated on the basis of the constant infusion technique compare favorably with the values obtained by the usual urine collection techniques in a series of patients with both normal and moderately reduced renal functions. Attention to a number of details is essential.

It should be stressed that great care must be taken in the interpretation of the $I V$ clearances in patients with reduced kidney function. In three such instances where the sustaining infusions had been calculated for clearances that had been overestimated, the $I V$ clearances were considerably higher than the true values, in spite of constant plasma drug levels. ${ }^{4}$ When the infusions were based on more accurately estimated clearances good correspondence between the two techniques was obtained, even though the filtration rate was very low. Unfortunately, the existence of apparently stable plasma inulin and $\mathrm{PAH}$ levels during the three experiments discussed above makes it impossible to be certain, without simultaneous urine collections, that the infusion technique clearances represent true values when renal functions are less than 60 per cent of normal.

In contrast to the situation described above, lack of equilibrium in the presence of edema was readily indicated by changing plasma drug levels. In the presence of any significant amount of edema, equilibrium is difficult to achieve. It is felt, however, that successful $I V$ clearances could be obtained under these circumstances if the proper relations between the priming and sustaining infusions and the excretory rate could be achieved, and if a considerably prolonged period for equilibrium were allowed.

Under a variety of circumstances where inulin or PAH clearances were acutely altered, the infusion technique values showed the same directional changes as were indicated by the $U V$ clearances, while the magnitudes of the $I V$ clearance changes were usually less. Although equilibrium is impossible under continously changing conditions such as were present in the experiments recorded in Table $I$, the infusion technique clearances reflected the actual changes with sufficient rapidity and at times with sufficient accuracy to suggest that the virtual volume of distribution of inulin and $\mathrm{PAH}$ concerned in the acute readjustments are considerably smaller than the true volumes of distribution as attained at equilibrium. Landowne and Alving (13) have commented that a prolonged period of time would be required for a given change in renal function to be reflected by significant changes in plasma drug concentrations. Their calculations, however, were based on the assumption that the redistribution of the compounds would immediately involve all extracellular fluid.

In addition to the measurement of glomerular filtration rate and renal plasma flow by the infusion technique it is possible to measure $T m_{\text {PAH }}$. When the load of PAH (see Methods) to $T m_{\mathbf{P A H}}$ ratio is kept between 2 and 4, reasonably good checks between the infusion and urine collection techniques were obtained. 


\section{SU M MARY}

1. Good correlations between the infusion and urine collection techniques for measuring glomerular filtration rate and effective renal plasma flow were obtained in 45 experiments with inulin and 26 experiments with $\mathrm{PAH}$ in subjects with normal or moderately reduced renal function, and who did not have more than minimal edema.

2. The infusion technique may be applied to the measurement of the maximal rate of excretion of $\mathrm{PAH}$ by the renal tubules.

3. Unsuccessful attempts to measure renal function by the infusion technique resulted from failure to attain equilibrium between the rates of infusion and excretion, especially in the presence of edema.

4. The infusion technique clearance may be erroneous in short experiments in subjects whose clearances are less than 60 per cent of normal. It is not possible in this circumstance to detect the erroneous experiments without concomitant urine collection clearances.

5. The infusion technique clearances reflect acute changes in filtration rate and renal plasma flow, but are usually damped in magnitude.

\section{BIBLIOGRAPHY}

1. Earle, D. P., and Berliner, R. W., A simplified clinical procedure for measurement of glomerular filtration rate and renal plasma flow. Proc. Soc. Exper. Biol. \& Med., 1946, 62, 262.

2. Smith, H. W., Goldring, W., and Chasis, H., The measurement of tubular excretory mass, effective blood flow and filtration rate in normal human kidney. J. Clin. Invest., 1938, 17, 263.

3. Smith, H. W., Finkelstein, N., Aliminosa, L., Crawford, B., and Graber, M., The renal clearances of substituted hippuric acid derivatives and other aromatic acids in dog and man. J. Clin. Invest., 1945, 24, 388.

4. Harrison, H. E., A modification of the diphenylamine method for determination of inulin. Proc. Soc. Exper. Biol. \& Med., 1942, 49, 111.

5. Alving, A. S., Rubin, J., and Miller, B. F., A direct colorimetric method for the determination of inulin in blood and urine. J. Biol. Chem., 1939, 127, 609.

6. Somogyi, M., Method for preparation of blood filtrates for determination of sugar. J. Biol. Chem., 1930, 86, 655.

7. Bratton, A. C., and Marshall, E. K., Jr., A new coupling component for sulfanilamide determination. J. Biol. Chem., 1939, 128, 537.

8. Smith, H. W., Personal communication.

9. Crawford, B., Depression of the exogenous creatinine/ inulin or thiosulfate clearance ratios in man by diodrast and p-aminohippurate acid. J. Clin. Invest., 1948, 27, 171.

10. Berger, E. Y., Farber, S. J., and Earle, D. P., The renal excretion of mannitol. Proc. Exper. Biol. \& Med., 1947, 66, 62.

11. Chasis, H., Ranges, H. A., Goldring, W., and Smith, H. W., The control of renal blood flow and glomerular filtration in normal man. J. Clin. Invest., 1938, 17, 683.

12. Berger, E. Y., and Earle, D. P., Unpublished observations.

13. Landowne, M., and Alving, A. S., A method of determining the specific renal functions of glomerular filtration, maximal tubular excretion (or re-absorption), and "effective blood flow," using a single injection of a single substance. J. Lab. \& Clin. Med., 1947, 32, 931. 